\title{
Synthesis and structural characterization of $\mathrm{Pd}(\mathrm{II})$ and $\mathrm{Cu}(\mathrm{I})$ complexes containing dithiophosphorus ligand and their catalytic activities for Heck reaction
}

\author{
Khodayar Gholivand, ${ }^{\mathrm{a},}$, Rasoul Salami ${ }^{\mathrm{a}}$, Kaveh Farshadfar ${ }^{\mathrm{a}}$, Raymond J. Butcher ${ }^{\mathrm{b}}$ \\ ${ }^{a}$ Department of Chemistry, Faculty of Sciences, Tarbiat Modares University, Tehran, Iran \\ ${ }^{b}$ Department of Chemistry, Howard University, Washington, D.C. 20059
}

* Corresponding author’s E-mail address: gholi_kh@modares.ac.ir

Tel.: +98 21 82883443; Fax: +98 218006544 . 


\begin{abstract}
2,4-bis(4-methoxyphenyl)-1,3,2,4-dithiadiphosphetane-2,4-disulfide (Lawesson's reagent) was made to react with benzylamine to produce $\left[\left(\mathrm{PhCH}_{2} \mathrm{NH}\right)\left(\mathrm{p}-\mathrm{C}_{6} \mathrm{H}_{4} \mathrm{OMe}\right) \mathrm{PS}_{2}\right]^{-}\left[\mathrm{PhCH}_{2} \mathrm{NH}_{3}\right]^{+}$in a very facile manner. From the abovementioned product, two new complexes $\left\{\mathrm{Pd}\left[\left(\mathrm{PhCH}_{2} \mathrm{NH}\right)(\mathrm{p}-\right.\right.$ $\left.\left.\left.\mathrm{C}_{6} \mathrm{H}_{4} \mathrm{OMe}\right) \mathrm{PS}_{2}\right]_{2}\right\}(\mathrm{C} 1)$ and $\left\{\mathrm{Cu}_{2}\left(\mathrm{PPh}_{3}\right)_{2}\left[\left(\mathrm{PhCH}_{2} \mathrm{NH}\right)\left(\mathrm{p}-\mathrm{C}_{6} \mathrm{H}_{4} \mathrm{OMe}\right) \mathrm{PS}_{2}\right]_{2}\right\}$ (C2) were obtained in high yields whose molecular structures were ascertained by X-ray diffraction analysis, IR and NMR spectroscopy, and elemental analysis. The catalytic properties of both complexes were evaluated in the Heck reaction. High turnover numbers (TONs) and yields were observed for palladium catalyst and It was revealed that dicopper(I) complex by a distance of $2.84 \AA$ between metal ions, bearing triphenylphosphine and dithiophosphorus ligands, can catalyze the Heck reaction. This is the first report of $\mathrm{Cu}(\mathrm{I})$ complex as catalyst in the Heck reaction. Natural bonding orbital (NBO) analysis for $\mathrm{C} 1$ indicated that natural charge on $\mathrm{Pd}$ atom is $-0.07 \mathrm{e}$ and $\mathrm{Pd}$ atom has formed four sigma bonds with $\mathrm{S}$ atoms. Similarly, NBO analysis revealed no significant $\mathrm{Cu} . . \mathrm{Cu}$ interaction in dicopper complex $\mathrm{C} 2$.
\end{abstract}

Keywords: Copper, Palladium, Dithiophosphorus Ligand, NBO analyses, Heck Reaction, 


\section{Introduction}

Nowadays the Mizoroki-Heck or simply the Heck reaction, catalyzed by transition-metal complexes, has become one of the most powerful and versatile tools in the formation of carboncarbon bonds which provides a basis for synthesizing a variety of important compounds used in many areas such as pharmaceuticals, antioxidants, drug intermediates, UV absorbers and industrial applications [1-4]. The catalytic performances of transition-metal complexes are strongly dependent upon the nature of their ligands and the donor groups and thus, ligand design is substantial to improvement of catalytic science. In this regard, the ancillary ligands play a key role in the steric and electronic properties of the catalyst complexes. Moreover, the ligands are determinative in the stability of the active species and catalyst lifetime $[5,6]$.

In recent years, dithiophosphorus (DTP) derivatives come into focus owing to the potential application as extraction agents for actinides from lanthanides via liquid/liquid extraction [7-11]. It has been shown that dithiophosphorus ligands are exceptional for this extraction as they are classified as soft-donor species [7-14]. Furthermore, dithiophosphorus ligands can be coordinated to the main group and transition metals, in particular, with soft metal centers such as palladium(II) and copper(I) $[15,16]$. DTPs are common bidentate ligands that can create stable complexes with soft acid type cations. Since in most homogeneous catalytic processes in C-C bond coupling based on palladium, the formation of palladium aggregates is common under the reaction conditions (which considerably reduces the catalytic activity), the use of stable palladium(II) complexes as catalyst help achieve highest turnover numbers [17-19]. Some of Pd(II) complexes with stabilizer chelating ligands showed very good catalytic activity in the Heck reaction [17-21]. But mechanistic details and, particularly, the question of how these stable complexes allow active species to be formed in catalytic cycle remain still unsolved.

Among transition-metal catalysts, palladium was mostly utilized for Heck coupling of aryl halides with olefins. Despite this fact, there are few reports on the use of copper for this reaction [22-26].However, there is a growing interest in using less expensive transition metal catalysts due to the high price of palladium.

In the present paper, we prepared two novel complexes of $\mathrm{Pd}(\mathrm{II})$ and $\mathrm{Cu}(\mathrm{I})$ with dithiophosphorus ligand (scheme 1) whose structural characterization and electronic properties 
were studied by X-ray crystallography and NBO analyses. The catalytic activity of both complexes in the Heck reaction was investigated.

\section{Results and discussion}

\subsection{Spectral characterization}

Ligand $\left[\mathrm{PhCH}_{2} \mathrm{NH}_{3}\right] \mathrm{L}$ was synthesized by reaction of two equivalent of benzylamine with one equivalents of Lawesson's reagent in toluene, giving 94\% yield. The ligand was used for preparation of new complexes labeled with $\mathrm{C} 1\left(\mathrm{PdL}_{2}\right)$ and $\mathrm{C} 2\left(\mathrm{Cu}_{2}\left(\mathrm{PPh}_{3}\right)_{2} \mathrm{~L}_{2}\right)$, Scheme 1 .

The infrared spectra of the C1 complex showed strong and medium-strong IR bands at 655 and $543 \mathrm{~cm}^{-1}$ which are ascribed to $v_{\text {asym }}(\mathrm{PS})$ and $v_{\text {sym }}$ (PS), respectively. Similarly, two strong IR bonds at 646 and $524 \mathrm{~cm}^{-1}$ were observed in the spectra of C2 complex for $v_{\text {asym }}$ (PS) and $v_{\mathrm{sym}}$ (PS), respectively. A number of studies suggest that the interval between the position of symmetric and asymmetric P-S bonds $(\Delta v)$ can be used to estimate the coordination mode of the dithiophosphinate ligands [27-31]. Based on the literature [27-31], $\Delta v$ values larger than $95 \mathrm{~cm}^{-1}$ are observed when dithiophosphinate ligands are monodentate. We found $\Delta v$ value of 112 and $124 \mathrm{~cm}^{-1}$ for $\mathrm{C} 1$ and $\mathrm{C} 2$ complexes respectively, even though the X-ray data showed bidentate chelating ligand for both complexes.

Cis and trans isomers are able to be formed regarding the nature of the chelating asymmetrical ligands in $\mathrm{C} 1$. The solid state structure shows that the trans isomer is the only present one in single crystals. The phosphorus atoms of cis and trans isomers are not chemically equivalent, because the cis isomer has a dipole moment and no inversion center, while the trans isomer has an inversion center and no dipole moment [32]. The ${ }^{31} \mathrm{P}\left\{{ }^{1} \mathrm{H}\right\}$ NMR spectrum for $\mathrm{C} 1$ reveals two singlet peaks at 91.38 and $92.32 \mathrm{ppm}$ by separation of about $1 \mathrm{ppm}$. It seems that these two peaks are related to two isomers of cis and trans [32]. As the crystals are dissolved in the solvent, the trans isomer quickly rearranges and also forms cis isomer. The ${ }^{1} \mathrm{H}$ NMR spectrum of $\mathrm{C} 1$ for OMe protons shows distinct peaks for each isomer: two singlet peaks at 3.80 and $3.83 \mathrm{ppm}$. The protons of $\mathrm{CH}_{2}$ moiety and phenyl groups show multiplets with overlap of the peaks of the two isomers. The ${ }^{31} \mathrm{P}\left\{{ }^{1} \mathrm{H}\right\}$ NMR spectra of $\mathrm{C} 2$ displays two doublet peak ( $\mathrm{PS}_{2}$ and $\mathrm{PPh}_{3}$ moiety) with a coupling constant $\left({ }^{3} j_{\mathrm{PP}}\right)$ at around $7 \mathrm{~Hz}$. 


\subsection{Crystal structure}

An ORTEP view of one molecule of $\mathrm{C} 1$ with atom numbering scheme is given in Fig. 1, and relevant bond distances and angles are presented in Table 1 . The $\operatorname{Pd}(\mathrm{II})$ is coordinated in a square-planar fashion with the four sulfur atoms from two chelating dithiophosphorus ligands, resulting in the formation of the four-membered chelate rings. The sum of bond angles around palladium is exactly $360^{\circ}$, indicating that the center atom and four sulfur atoms are located in the same plane. The S1-Pd-S1A and S2-Pd-S2A angles are $180.00^{\circ}$, which shows no deviation from linearity, while the S1-Pd-S2 $\left(83.90(\mathbf{1 5})^{\circ}\right)$ and S1-Pd-S2A $\left(96.09(\mathbf{1 5})^{\circ}\right)$ are not equal and display deviation from the ideal value of $90^{\circ}$. The palladium-sulfur bond lengths of 2.3426(4) and 2.3431(4) $\AA$ are within the normal Pd-S range of 2.2-2.5 $\AA[33,34]$ and are close to those found in phosphine sulfide palladium complexes [35-37]. Approximately, equal values of phosphorus-sulfur bond lengths, 2.0336(6) and 2.0156(6) $\AA$ demonstrate that the negative charge is delocalized throughout the S-P-S moiety. The P-N distance of 1.6282(15) $\AA$ in this complex is shorter than the P-N single bond [38].

The interesting feature of this structure is a short intermolecular contact, Pd...H14-C14, between palladium(II) centers with two $\mathrm{H}$ atoms of two adjacent molecules [fig. 2]. These contacts are established with donor-acceptor distances of $3.324 \AA$. Wang et al. have shown that similar short intermolecular contacts Pt...H-C (2.94-3.02 Å) exist in platinum(II) complexes [39]. Moreover, the $\mathrm{H} 14$ atoms are positioned on both sides of the $\mathrm{PdS}_{4}$ plan and, consequently they are oriented toward the $\mathrm{dz}^{2}$ orbital of palladium(II) center, with H14...Pd...H14 angle of $180.000^{\circ}$. These short contacts with the $\mathrm{Pd}$...H separation distance more than $2.2 \AA$ provide a $\mathrm{Pd}$...H-C interaction which can be regarded as a 3 center-4 electron $(3 \mathrm{c}-4 \mathrm{e})$ interaction using the electron pair in the $\mathrm{dz}^{2}$ orbital of the central atom [39-44], whereas many complexes of transition metal showing well-known M...H-C interaction described as agostic interaction (3c-2e) with the M...H separation distance in the range of 1.8-2.2 $\AA$ [39,45-47]. For Pd...H14-C14 contact, Intermolecular binding energy, $\Delta \mathrm{E}$, was calculated at the M062X/LANL2DZ/6-311++G(d,p) level to estimate the strength of this interaction. $\Delta \mathrm{E}$ value of $-5.21 \mathrm{kcal} \mathrm{mol}^{-1}$ was obtained for this contact, which is more than the strength of $\mathrm{C}-\mathrm{H} \ldots \pi$ interactions $\left(2-4 \mathrm{kcal} \mathrm{mol}^{-1}\right)$ and is comparable with nonclassical intermolecular hydrogen bonds $\left(5-9 \mathrm{kcal} \mathrm{mol}^{-1}\right)[48,49]$. 


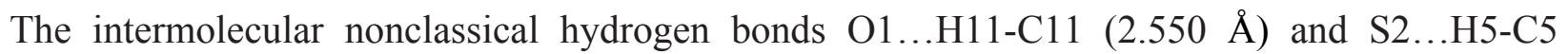
$(2.791 \AA)$ link the molecules together in the solid state and generate a two-dimensional (2D) framework [fig. 3]. The resulting 2D plans are further linked by S1...H1-N1 (2.56 §̊), Pd...H-C and C-H... $\pi$ [fig. 2] to generate 3D supramolecular network.

As shown in Fig. 1, Complex $\mathrm{C} 2$ is a dicopper compound which each $\mathrm{Cu}(\mathrm{I})$ cation is tetrahedrally coordinated by three sulfurs and one triphenylphosphine and the resultant dinuclear structure contains two $\mathrm{CuPS}_{2}$ and one $\mathrm{Cu}_{2} \mathrm{~S}_{2}$ rings. The $\mathrm{L}$ ligand acts as chelating ligand via its two sulfur atoms in way that the one sulfur atom is bridged between two copper and the other sulfur atom coordinates only to one copper. The $\mathrm{Cu}_{2} \mathrm{~S}_{2}$ ring shows a particular geometry with alternative long $(2.6147(6) \AA)$ and short (2.3085(6) $\AA) \mathrm{Cu}-\mathrm{S}$ distances due to the nature of the orbitals and electrons of the bridging sulfur [50,51]. The $\mathrm{Cu}-\mathrm{P}(\mathrm{Cu}-\mathrm{P} 2, \mathrm{CuA}-\mathrm{P} 2 \mathrm{~A})$ and $\mathrm{Cu}-$ terminal S (Cu-S1, CuA-S1A) lengths are 2.2220(5) and 2.3857(6), respectively, which fall within the range of copper(I) dithiocomplexes [52,53]. Regarding the fact that the sum of van der Waals radii for two copper is ca. $2.8 \AA$ [54], the observed $\mathrm{Cu}-\mathrm{Cu}$ distance (2.8396(5) $\AA$ ) suggests the minor contribution of $\mathrm{Cu} \cdots \mathrm{Cu}$ interaction. The bond angles around $\mathrm{Cu}(\mathrm{I})$ are in the range of $84.050(16)^{\circ}-127.633(19)^{\circ}$ for the $\mathrm{S} 1-\mathrm{Cu}-\mathrm{S} 2$ and $\mathrm{P} 2-\mathrm{Cu}-\mathrm{S} 2$ angles, respectively. Each of four-membered ring $\mathrm{Cu}_{2} \mathrm{~S}_{2}$ and $\mathrm{CuPS}_{2}$ (sum of internal angles in the range of 359-360 ${ }^{\circ}$ ) are flat. The torsion angle between the two planes $\mathrm{CuPS}_{2}$ is $0.0^{\circ}$ and each of these rings generates the angle $73.359(17)^{\circ}$ with $\mathrm{Cu}_{2} \mathrm{~S}_{2}$, thus indicating that the $\mathrm{CuPS}_{2}$ planes are approximately perpendicular to the $\mathrm{Cu}_{2} \mathrm{~S}_{2}$ plane. The P-S distance for $\mathrm{S}$ in terminal position (P1-S1, P1A-S1A = $1.9914(7) \AA)$ is slightly shorter than the P-S distance in bridging position (P1-S2, P1A-S2A = 2.0329(6) $\AA$ ).

In this crystal structure, the sulfur atoms, as bifurcated acceptors, are involved in intermolecular C-H...S1 nonclassical hydrogen bonds that lead to the formation of 2D framework [fig. 4]. In these interactions, the C-H...S1 distances are 2.925 and $3.011 \AA$. The cooperation of nonclassical hydrogen bonds with multiple weaker $\mathrm{C}-\mathrm{H} \ldots \pi$ and $\mathrm{C}-\mathrm{H} \ldots \mathrm{H}-\mathrm{C}$ interactions leads to generation of 3D supramolecular network.

It is noteworthy, that no $\mathrm{S} \cdots \mathrm{S}$ intermolecular stacking, often found in dithiocomplexes, was detected in the $\mathrm{C} 1$ and $\mathrm{C} 2$ complexes (probably because of the steric bulk of the ligands). 


\subsection{Theoretical calculations}

Full geometry optimization of dithiophosphorus ligand $\mathrm{L}, \mathrm{C} 1$ and $\mathrm{C} 2$ complexes were performed using DFT calculation with B3LYP functional and also, NBO analyses were carried out to gain more insight about bonding and electronic aspects of the complexes. The obtained optimized geometries of the compounds are shown in fig. 5 and some selected geometric parameters are listed in Table 1. The optimized structure of $\mathrm{C} 1$ reproduces the square-planar coordination surrounding the palladium center and its geometric parameters show good agreement with the Xray structure of $\mathrm{C} 1$. The comparison of the calculated $\mathrm{P}-\mathrm{S}$ bond lengths in $\mathrm{L}$ and $\mathrm{C} 1$ reveal the lengthening of the $\mathrm{P}-\mathrm{S}$ bonds from free ligand $\mathrm{L}$ to $\mathrm{C} 1$ and $\mathrm{C} 2$ complexes. $\mathrm{Cu}$... Cu distance in the optimized C2 structure is larger by $0.896 \AA$ than the corresponding one in solid state structure. As can be seen in fig. 5, the optimized structure of $\mathrm{C} 2$ comprises an eight-membered $\mathrm{Cu}_{2} \mathrm{P}_{2} \mathrm{~S}_{4}$ ring in which two $\mathrm{Cu}$ are bridged by two $\mathrm{S}$ atoms of the $\mathrm{L}$ ligands. The minimum calculated energy for $\mathrm{C} 2$ in the observed structure at the solid state is slightly higher compared to the optimized one in gas phase $\left(\Delta \mathrm{E}=8.74 \mathrm{kcal} \mathrm{mol}^{-1}\right)$. However, this structure can be stabilized (as observed in the X-ray structure) by intermolecular interactions with neighboring molecules, which is a determinant factor in the solid state structure.

\subsection{NBO analysis}

Initially, it's noteworthy that $\mathrm{NBO}$ analyses for $\mathrm{C} 1$ and $\mathrm{C} 2$ were performed on optimized structures cut out from X-ray structures by freezing non-hydrogen atoms. Table 2 shows that in $\mathrm{C} 1$ complex, the negative charges on sulfur atoms decrease by an average value about $0.34 \mathrm{e}$ upon complexation, indicating the strong donor-acceptor interactions between the metal atom and the sulfur atoms. But in $\mathrm{C} 2$ complex the negative charges on sulfur atoms increase by an average value about 0.06e upon complexation, owing to the electrostatic field of $\mathrm{Cu}(\mathrm{I})$ ion [55]. The positive charge on phosphorus atom increases from L ligand to complexes. Meanwhile, no significant $\pi$-bond contribution for P-S bonds was observed in any of the compounds within the NBO framework. The electron configuration of palladium in $\mathrm{Cl}$ is [core] $5 \mathrm{~s}^{0.37} 4 \mathrm{~d}^{9.19} 5 \mathrm{p}^{0.49} 6 \mathrm{~s}^{0.01} 5 \mathrm{~d}^{0.01}$, indicating nearly full occupation of the $4 \mathrm{~d}$ orbital by 9.19 electrons. The sum of core electrons (36e), valance electrons (9.56e on 5s and 4d) and Rydberg electrons ( $0.51 \mathrm{e}$ on $5 \mathrm{p}, 6 \mathrm{~s}$ and $5 \mathrm{~d})$ give 46.07 electrons in agreement with the calculated natural charge of $-0.07 \mathrm{e}$ at $\mathrm{Pd}$ atom. According to the $\mathrm{NBO}$, the Pd atom forms four sigma bonds with $\mathrm{S}$ 
atoms as a result of electron donation from the $\mathrm{S}$ lone pairs to the $\mathrm{Pd}$ orbitals in which $\sigma(\mathrm{Pd}-\mathrm{S})$ bonds are strongly polarized toward sulfur atoms (ca.79\% at S). Therefore, as a consequence of electron density donation from $\mathrm{S}$ to Pd, the positive charge of Pd(II) was fully compensated. The hybrid of $\sigma(\mathrm{Pd}-\mathrm{S})$ bonds on $\mathrm{Pd}$ atom is a mixture of s (24.35-24.50\%), p (50.00\%) and $\mathrm{d}$ (26.50-26.65 \%) and also is a mixture of s (11.64-11.70\%), p (88.15-88.21\%) and $\mathrm{d}(0.15 \%)$ on $\mathrm{S}$ atoms. The bonding orbital are occupied by about $1.82 \mathrm{e}$ for Pd-S bonds.

As follows from Table 2, the calculated charge distribution of +0.829 for $\mathrm{Cu}$ atoms in $\mathrm{C} 2$ complex is also consistent with the electron configuration of $\mathrm{Cu}$, [core] $4 \mathrm{~s}^{0.40} 3 \mathrm{~d}^{9.74} 4 \mathrm{p}^{0.02} 5 \mathrm{~S}^{0.01}$. In bonding the $\mathrm{L}$ ligand and triphenylphosphine to $\mathrm{Cu}$ atoms, no $\sigma$-bond is found in the NBO analysis, and the bonds of $\mathrm{Cu}$ with $\mathrm{S}$ or $\mathrm{P}$ can be described as predominant Coulomb-type interactions [56]. According to the NBO, the amount of delocalization of electron density between occupied Lewis-type orbitals, LP (S or P), and unoccupied non-Lewis orbitals, LP* $(\mathrm{Cu})$, corresponds to a stabilizing donor-acceptor interaction. The calculated second order interaction energy $\left(\mathrm{E}^{2}\right)$ between donor-acceptor orbitals can be used as a measure of interaction strength. A strong donor-acceptor interaction by $\mathrm{E}^{2}=99.69 \mathrm{kcal} \mathrm{mol}^{-1}$ was found between $\mathrm{P}$ atom of $\mathrm{PPh}_{3}$ and $\mathrm{Cu}$ atom. The other strong interaction was observed between terminal $\mathrm{S}$ atom of $\mathrm{L}$ ligand and $\mathrm{Cu}$ atom by $\mathrm{E}^{2}=56.25 \mathrm{kcal} \mathrm{mol}^{-1}$. Two actually different energies of 28.27 and $67.02 \mathrm{kcal} \mathrm{mol}^{-1}$ were found for the interaction of bridge $\mathrm{S}$ atom with the two $\mathrm{Cu}$ atoms. Similarly, within the NBO framework, no significant $\mathrm{Cu}$... Cu interaction was observed at $\mathrm{E}^{2}$ higher than $3.1 \mathrm{kcalmol}^{-1}$.

\subsection{Catalytic Performance of the $C 1$ and $C 2$ complexes in the Heck Reaction}

Initially, we evaluated the thermal stability of $\mathrm{C} 1$ after prolonged heating at $180{ }^{\circ} \mathrm{C}$ in $\mathrm{N}$ methylpyrrolidone (NMP) by ${ }^{31} \mathrm{P}\left\{{ }^{1} \mathrm{H}\right\}$ NMR spectrum. After three days, no decomposition and no palladium black were observed for the compound. Catalytic studies of the complexes in Heck reaction between bromobenzene and styrene have been performed to survey reaction parameters. The screening results presented in Table 3 show that the polar aprotic solvent $\mathrm{N}$ methylpyrrolidinone (NMP) and N,N-dimethylformamide (DMF) obtain better results than other solvents. The non-polar solvents such as toluene and dioxane gave comparatively similar yield (entries 4,5) but below that of DMF and NMP. The polar protic solvent such as isopropanol gave the lowest yields (entry 3). We then used DMF as the optimal solvent to find the best base. We 
screened several inorganic and organic bases such as $\mathrm{K}_{2} \mathrm{CO}_{3}, \mathrm{~K}_{3} \mathrm{PO}_{4}, \mathrm{NaOH}, \mathrm{Et}_{3} \mathrm{~N}$ and pyridine. Accordingly, inorganic bases obtained higher yields than organic bases [table 3]. Of the three inorganic bases, $\mathrm{K}_{2} \mathrm{CO}_{3}$ and $\mathrm{K}_{3} \mathrm{PO}_{4}$ gave the highest yields of the desired product for Catalyst $\mathrm{C} 1$ (entry 1) and Catalyst $\mathrm{C} 2$ (entry 6), respectively. A comparatively similar result was observed using $\mathrm{K}_{2} \mathrm{CO}_{3}$ and $\mathrm{K}_{3} \mathrm{PO}_{4}$ as a base for $\mathrm{C} 1$ catalyst, but for $\mathrm{C} 2$ catalyst the reaction would be much slower if $\mathrm{K}_{2} \mathrm{CO}_{3}$ was replaced with a stronger base $\mathrm{K}_{3} \mathrm{PO}_{4}$ (entries 1,6 ).

Furthermore, the optimizations of catalyst loading were performed in DMF as a reaction solvent in the presence of $\mathrm{K}_{2} \mathrm{CO}_{3}$ for $\mathrm{C} 1$ catalyst and $\mathrm{K}_{3} \mathrm{PO}_{4}$ for $\mathrm{C} 2$ catalyst to determine the most efficient of catalyst amount [table 4]. Increasing the amount of $\mathrm{C} 1$ from 0.00002 equivalent (equiv.) in coupling of bromobenzene $(\mathrm{PhBr})$ with styrene had no considerable impact on the yield but caused to a decrease in turnover number (TON) certainly. When iodobenzene (PhI) was used instead of $\mathrm{PhBr}$, even $\mathrm{C} 1$ loading of 0.00001 equiv. (entry 9) gave $100 \%$ yield. Various amounts of $\mathrm{C} 2$ were also examined and the best results were obtained in 0.03 and 0.10 equiv. [table 4, entries 17, 14] for coupling of $\mathrm{PhI}$ and $\mathrm{PhBr}$, respectively. As shown in table 4, C1 complex is a more robust catalyst compared to $\mathrm{C} 2$, but considering economy and toxicity, the use of the $\mathrm{C} 2$ complex as the catalyst can be more attractive.

The time-yield plot of the coupling of the bromobenzene with styrene under copper catalyst displays a sigmoidal-shaped curve with an induction period of $30 \mathrm{~min}$ and then reveals an exponential increase in the yield of the reaction [fig. 6]. These observations suggest that the copper complex acts as precursor to form catalytically active species. There have been few reports of a similar activation step for palladium (II) complexes [57-60]. Furthermore, no induction period is observed in the time-yield plot of palladium catalyst in the examined time intervals and the catalyst should be immediately active at the beginning of the reaction. After $8 \mathrm{~h}$, none of the catalysts showed considerable increment in the yield.

Since NBO analysis revealed that four strong sigma bonds Pd-S for stable palladium complex (C1) and that no induction period was observed in the time-yield plot of $\mathrm{C} 1$, it can be concluded that $\mathrm{Cl}$ acts as a catalytically active species in catalytic cycle, probably, without being dissociated Pd-S bonds. Moreover, it is worth noting that a number of $\mathrm{Cu}(\mathrm{I})$ complexes built in our group were investigated for coupling aryl bromides with styrene, out of which only $\mathrm{C} 2$ complex was able to perform this coupling. 


\section{Conclusion}

The new air and thermally stable complex of palladium(II) $\left\{\mathrm{Pd}\left[\left(\mathrm{PhCH}_{2} \mathrm{NH}\right)\left(\mathrm{p}-\mathrm{C}_{6} \mathrm{H}_{4} \mathrm{OMe}\right) \mathrm{PS}_{2}\right]_{2}\right\}$ (C1) and the dicopper(I) complex $\left\{\mathrm{Cu}_{2}\left(\mathrm{PPh}_{3}\right)_{2}\left[\left(\mathrm{PhCH}_{2} \mathrm{NH}\right)\left(\mathrm{p}-\mathrm{C}_{6} \mathrm{H}_{4} \mathrm{OMe}\right) \mathrm{PS}_{2}\right]_{2}\right\}$ (C2) were prepared in satisfactory yields and characterized using X-ray diffraction analysis, IR and NMR spectroscopy, and elemental analysis. Based on NBO analysis and time-yield plot, we suggest that the $\mathrm{C} 1$ complex probably acts as a catalytically active species, not as a precatalyst, in catalytic cycle of the Heck reaction. Although copper complexes are often not active in the Heck reaction, the present study suggests that the dicopper complex with the metal ions separated by $2.84 \AA$ is an effective catalyst for the Heck reaction.

\section{Experimental section}

\subsection{Materials and methods}

All chemicals and solvents are commercially available, and used without further purification. Drying of the solvents was done using standard methods. Melting points were obtained by an electrothermal instrument. Elemental analyses were performed using a Heraeus CHN-O-RAPID apparatus. Infrared spectra were recorded $\left(400-4000 \mathrm{~cm}^{-1}\right.$ region) on a Nicolet 510P spectrophotometer using $\mathrm{KBr}$ disk. ${ }^{31} \mathrm{P}\left\{{ }^{1} \mathrm{H}\right\}$ NMR spectra were obtained on a Bruker Avance DRX-500 spectrometer operating at $202 \mathrm{MHz}$ with chemical shifts reported relative to a $85 \%$ $\mathrm{H}_{3} \mathrm{PO}_{4}$ in $\mathrm{D}_{2} \mathrm{O}$ external standard solution. ${ }^{1} \mathrm{H}$ NMR spectra were also obtained on a Bruker Avance DRX-500 spectrometer with chemical shifts relative to the internal standard TMS. The Heck coupling reactions were analyzed by HP Agilent 6890 gas chromatograph equipped with a HP-5 capillary column and flame-ionization detector.

\subsection{Preparation of $\left[\left(\mathrm{OCH}_{3} \mathrm{C}_{6} \mathrm{H}_{4}\right)\left(\mathrm{phCH}_{2} \mathrm{NH}\right) \mathrm{PS}_{2}\right]^{-}\left[\mathrm{phCH}_{2} \mathrm{NH}_{3}\right]^{+}\left([\mathrm{L}]\left[\mathrm{phCH}_{2} \mathrm{NH}_{3}\right]^{+}\right)$}

Titled compound was prepared using reported method [61]. To a suspension of Lawesson's reagent $(0.404 \mathrm{~g}, 1 \mathrm{mmol})$ in $10 \mathrm{~mL}$ dry toluene at room temperature, benzylamine $(0.536 \mathrm{~g}, 5$ $\mathrm{mmol}$ ) was added and the mixture was stirred for $6 \mathrm{~h}$. The colorless precipitated solid was filtered off and washed several times with dry toluene. The structure of ligand $\mathrm{L}$ is given in scheme 1 . Yield 94\%, M.p. $164{ }^{\circ} \mathrm{C}$. Anal. Calc. for $\mathrm{C}_{21} \mathrm{H}_{25} \mathrm{~N}_{2} \mathrm{OPS}_{2}$ (416.45): C, 60.56; H, 6.00; N, 6.73 . Found: C, 60.60; H, 5.98; N, 6.76\%. IR (KBr, $\left.\mathrm{cm}^{-1}\right): v=3321(\mathrm{~m}), 2925(\mathrm{br}), 2853(\mathrm{br}), 1587(\mathrm{~s})$, 1491(s), 1451(m), 1395(w), 1290(w), 1249(s), 1180(w), 1103(m), 1056(m), 964(w), 817(br), 
742(m), 696(m), 661(s, vasym (PS)), 587(m), 545(s, $\left.v_{\text {sym }}(\mathrm{PS})\right) .{ }^{1} \mathrm{H}$ NMR (500.13 MHz, DMSO$\mathrm{d} 6): \delta(\mathrm{ppm})=3.21(\mathrm{br}, 1 \mathrm{H}, \mathrm{NH}($ anion moiety $)), 3.73\left(\mathrm{~s}, 3 \mathrm{H}, \mathrm{OCH}_{3}\right), 3.78\left(\mathrm{t},{ }^{3} \mathrm{~J}_{\mathrm{PH}}=8.9 \mathrm{~Hz}, 2 \mathrm{H}\right.$, $\mathrm{CH}_{2}$ (anion moiety)), 4.02(s, $2 \mathrm{H}, \mathrm{CH}_{2}$ (cation moiety)), 6.78(d, $\left.{ }^{3} \mathrm{JHH}=4.3 \mathrm{~Hz}, 1 \mathrm{H}\right), 6.80\left(\mathrm{~d},{ }^{3} \mathrm{~J}_{\mathrm{HH}}=\right.$ $4.65 \mathrm{~Hz}, 1 \mathrm{H}), 7.12\left(\mathrm{t},{ }^{3} \mathrm{~J}_{\mathrm{HH}}=6.95 \mathrm{~Hz}, 1 \mathrm{H}\right), 7.19-7.24(\mathrm{~m}, 4 \mathrm{H}), 7.35-7.45(\mathrm{~m}, 5 \mathrm{H}), 7.90\left(\mathrm{dd},{ }^{3} \mathrm{~J}_{\mathrm{HH}}=\right.$ $\left.4.70 \mathrm{~Hz},{ }^{3} \mathrm{JHH}_{\mathrm{HH}}=6.74 \mathrm{~Hz}, 1 \mathrm{H}\right), 7.94\left(\mathrm{dd},{ }^{3} \mathrm{~J}_{\mathrm{HH}}=5.36 \mathrm{~Hz},{ }^{3} \mathrm{~J}_{\mathrm{HH}}=6.18 \mathrm{~Hz}, 1 \mathrm{H}\right) .{ }^{31} \mathrm{P}\left\{{ }^{1} \mathrm{H}\right\}$ NMR (202.46 MHz, DMSO-d6): $\delta(\mathrm{ppm})=80.25$ (s)

\subsection{Preparation of $\mathrm{Cl}$ complex $\left\{\mathrm{Pd}\left[\left(\mathrm{PhCH} \mathrm{CH}_{2} \mathrm{NH}\right)\left(\mathrm{p}-\mathrm{C}_{6} \mathrm{H}_{4} \mathrm{OMe}\right) \mathrm{PS}_{2}\right]_{2}\right\}\left(\mathrm{PdL} \mathrm{L}_{2}\right)$}

A solution of $\mathrm{PdCl}_{2}(0.086 \mathrm{~g}, 0.50 \mathrm{mmol})$ in acetonitrile $(5 \mathrm{ml})$ was added drop-wise to a solution of $\mathrm{L}(0.416 \mathrm{~g}, 1.00 \mathrm{mmol})$ in methanol $(5 \mathrm{ml})$ and the mixture was stirred for $8 \mathrm{~h}$ to obtain yellow clear solution. Suitable crystals for X-ray analysis were obtained by slow evaporation of solvent after 2 days. Yield 88\%, M.p. $181{ }^{\circ} \mathrm{C}$. Anal. Calc. for $\mathrm{C}_{28} \mathrm{H}_{30} \mathrm{~N}_{2} \mathrm{O}_{2} \mathrm{P}_{2} \mathrm{PdS}_{4}$ (723.17): C, 46.50; H, 4.15; N, 3.87. Found: C, 46.51; H, 4.12; N, 3.88\%. IR (KBr, $\left.\mathrm{cm}^{-1}\right): v=3235(\mathrm{vs}), 3015(\mathrm{br})$, 2928(s), 1589(s), 1495(s), 1457(m), 1403(m), 1296(m), 1252(vs), 1178(m), 1107(vs), 1060(vs), 1022(m), 967(w), 870(m), 825(m), 746(m), 695(m), 655(s, $\left.v_{\text {asym }}(\mathrm{PS})\right), 543\left(\mathrm{~s}, v_{\mathrm{sym}}(\mathrm{PS})\right) .{ }^{1} \mathrm{H}$ NMR (500.13 MHz, DMSO-d6): $\delta(\mathrm{ppm})=3.33(\mathrm{br}$, overlapping with the solvent signal, $\mathrm{NH}$ ), 3.80(s, $\left.3 \mathrm{H}, \mathrm{OCH}_{3}\right), 3.83\left(\mathrm{~s}, 3 \mathrm{H}, \mathrm{OCH}_{3}\right) 4.15(\mathrm{~m}, 4 \mathrm{H}), 6.94(\mathrm{~m}, 2 \mathrm{H}), 7.13(\mathrm{~m}, 2 \mathrm{H}), 7.23(\mathrm{~m}, 2 \mathrm{H})$, 7.31-7.42(m, 8H), 7.83.7.92(4H). ${ }^{31} \mathrm{P}\left\{{ }^{1} \mathrm{H}\right\} \mathrm{NMR}(202.46 \mathrm{MHz}, \mathrm{DMSO}-\mathrm{d} 6): \delta(\mathrm{ppm})=91.37(\mathrm{~s})$, 92.32(s).

\subsection{Preparation of C2 complex $\left\{\mathrm{Cu}_{2}\left(\mathrm{PPh}_{3}\right)_{2}\left[\left(\mathrm{PhCH}_{2} \mathrm{NH}\right)\left(\mathrm{p}-\mathrm{C}_{6} \mathrm{H}_{4} \mathrm{OMe}\right) \mathrm{PS}_{2}\right]_{2}\right\}\left(\mathrm{Cu}_{2}\left(\mathrm{PPh}_{3}\right)_{2} \mathrm{~L}_{2}\right)$}

A solution of $\mathrm{L}(0.416 \mathrm{~g}, 1.00 \mathrm{mmol})$ in chloroform $(12 \mathrm{~mL})$ was added drop wise to stirred solution of mixture copper(I) chloride $(0.134 \mathrm{~g}, 1.00 \mathrm{mmol})$ and triphenylphosphine $\left(\mathrm{PPh}_{3}\right)$ $(0.263 \mathrm{~g}, 1.00 \mathrm{mmol})$ in acetonitrile $(6 \mathrm{ml})$. The mixture of reaction was filtered off to obtain a colorless clear solution. Suitable single crystals of $\mathrm{C} 2$ were obtained by slow diffusion of diethyl ether in the clear solution. Yield 76\%, M.p. $233{ }^{\circ} \mathrm{C}$ (decompose). Anal. Calc. for $\mathrm{C}_{64} \mathrm{H}_{60} \mathrm{Cu}_{2} \mathrm{~N}_{2} \mathrm{O}_{2} \mathrm{P}_{4} \mathrm{~S}_{4}$ (1268.45): C, 60.60; H, 4.77; N, 2.21. Found: C, 60.59; H, 4.78; N, 2.19\%. IR $\left(\mathrm{KBr}, \mathrm{cm}^{-1}\right): v=3321(\mathrm{~m}), 3050(\mathrm{br}), 2905(\mathrm{br}), 1588(\mathrm{~m}), 1487(\mathrm{~m}), 1433(\mathrm{~m}), 1383(\mathrm{~m})$, 1287(w), 1251(m), 1174(m), 1097(s), 1055(m), 1024(m), 856(w), 802(m), 741(s), 692(s), 646(s, $\left.v_{\text {asym }}(\mathrm{PS})\right), 614(\mathrm{~m}), 575(\mathrm{~m}), 524\left(\mathrm{~s}, v_{\mathrm{sym}}(\mathrm{PS})\right) .{ }^{1} \mathrm{H}$ NMR (500.13 MHz, DMSO-d6): $\delta(\mathrm{ppm})=$ $3.18\left(\mathrm{dd},{ }^{2} \mathrm{~J}_{\mathrm{PH}}=21.4 \mathrm{~Hz},{ }^{3} \mathrm{~J}_{\mathrm{HH}}=7.2 \mathrm{~Hz}, 1 \mathrm{H}, \mathrm{NH}\right), 3.68\left(\mathrm{~s}, 3 \mathrm{H}, \mathrm{OCH}_{3}\right), 4.09\left(\mathrm{~d},{ }^{3} \mathrm{~J}_{\mathrm{HH}}=7.2 \mathrm{~Hz}, 2 \mathrm{H}\right.$, 
$\left.\mathrm{CH}_{2}\right), 6.73(\mathrm{~m}, 2 \mathrm{H}), 7.03\left(\mathrm{t},{ }^{3} \mathrm{~J}_{\mathrm{HH}}=6.23 \mathrm{~Hz}, 1 \mathrm{H}\right), 7.16-7.43(\mathrm{~m}$, overlapping with the solvent signal), 7.73(m, 2H). ${ }^{31} \mathrm{P}\left\{{ }^{1} \mathrm{H}\right\} \mathrm{NMR}(202.46 \mathrm{MHz}, \mathrm{DMSO}-\mathrm{d} 6): \delta(\mathrm{ppm})=-1.69\left(\mathrm{~d},{ }^{3} \mathrm{JP}=6.9 \mathrm{~Hz}\right.$, $\left.\mathrm{PPh}_{3}\right), 75.65\left(\mathrm{~d},{ }^{3} \mathrm{JPP}=7 \mathrm{~Hz}, \mathrm{PS}_{2}\right)$.

\subsection{Crystal structure determination}

Crystals were selected under a microscope and mounted on a MiTeGen cryoloop using mineral oil and transferred to a Bruker Quest diffractometer in a cold stream of nitrogen gas at $173.15^{\circ} \mathrm{C}$. Preliminary cell constants were obtained from a small set of frames and then a complete hemisphere of data was collected. The Bruker diffractometer control program Apex 2 was used for the preliminary setup and data collection [62]. The collected data was processed with the Bruker program Saint. A multi-scan type absorption correction was applied using SADABS [63]. The structure was solved using the program Superflip [64] and refined using Shelxl-2014. Files for publication and diagrams were prepared using Shelxtl [65]. Details of the $\mathrm{X}$-ray data collection parameters are given in Table 5.

\subsection{Theoretical methods}

All the DFT calculations reported here were carried out using Gaussian 03 package [66] in the gas phase. The structure of the free ligand and the two complexes was fully optimized at the B3LYP level [67]. The palladium atom was described by the LANL2DZ effective core potential and basis set [68], but the standard basis set $6-311+\mathrm{G}^{*}$ was used for remaining atoms. All the vibrational frequencies were real, indicating that the optimized structures to be minimal. Natural bond orbital (NBO) analyses [69] were performed at the B3LYP/6-311+G** level for $\mathrm{L}$ and $\mathrm{C} 2$ and at the B3LYP/6-311+G**/LANL2DZ level for C1.

In order to calculate binding energy $\mathrm{Pd} \ldots \mathrm{H}$ in solid state, two selected fragment were cut out from C1 X-ray structure and optimized by freezing of non-hydrogen atoms at the B3LYP/6$311+\mathrm{G}^{*} / \mathrm{LANL} 2 \mathrm{DZ}$ level. The intermolecular Pd...H energy was evaluated at M062X/6$311++\mathrm{G}^{* *} / \mathrm{LANL} 2 \mathrm{DZ}$ level, according to the energy difference between the total energy of the

system and its fragments. Basis set superposition error (BSSE) in the interaction energy has been removed by the counterpoise correction method of Boys and Bernardi [69].

\subsection{General procedure for preparative Heck reactions}


A reaction flask was charged with an appropriate amount of aryl halide (1.0 equiv.), styrene (1.2 equiv.), base (1.5 equiv.), dodecane as internal standard ( $40 \mathrm{mg})$, solvent $(2 \mathrm{~mL})$ and stirring bar. The resulting mixture was heated to $100{ }^{\circ} \mathrm{C}$ for several minutes before the prescribed amount of catalyst was added. After a specified period of time, the suspension was cooled to room temperature, water was added, and the product was extracted with $\mathrm{CH}_{2} \mathrm{Cl}_{2}$ (three times). The combined organic portions were dried over $\mathrm{MgSO}_{4}$, filtered, and evaporated under vacuum to achieve the desired product which was then washed with hexane. The coupled products were analyzed by a combination of GC analysis and NMR spectroscopy (comparison of NMR data with those in the literature).

\section{Acknowledgements}

Financial support of this work by Tarbiat Modares University is gratefully acknowledged. We thank also the assistance of Dr. Matthias Zeller for help in data collection and NSF Grant 1337296 for funds to obtain the diffractometer. 


\section{References}

[1] S. Liu, X. Jiang, G. Zhuo, Journal of Molecular Catalysis A: Chemical, 290 (2008) 72-78.

[2] Y.-M. Jhou, D. Nandi, J.-Y. Lee, R.-J. Tzeng, H.M. Lee, Polyhedron, 100 (2015) 28-35.

[3] J.L. Pratihar, P. Pattanayak, D. Patra, C.-H. Lin, S. Chattopadhyay, Polyhedron, 33 (2012) 67-73

[4] M. Aydemir, F. Durap, A. Baysal, O. Akba, B. Gümgüm, S. Özkar, L.T. Yıldırım, Polyhedron, 28 (2009) 2313-2320.

[5] I.P. Beletskaya, A.V. Cheprakov, Chemical Reviews, 100 (2000) 3009-3066.

[6] N.T. Phan, M. Van Der Sluys, C.W. Jones, Advanced Synthesis \& Catalysis, 348 (2006) 609-679.

[7] G.J. Lumetta, A.V. Gelis, G.F. Vandegrift, Solvent Extraction and Ion Exchange, 28 (2010) 287-312.

[8] F.W. Lewis, L.M. Harwood, M.J. Hudson, M.G. Drew, J.F. Desreux, G. Vidick, N. Bouslimani, G. Modolo, A. Wilden, M. Sypula, Journal of the American Chemical Society, 133 (2011) 13093-13102.

[9] S. Özçubukçu, K. Mandal, S. Wegner, M.P. Jensen, C. He, Inorganic chemistry, 50 (2011) 7937-7939.

[10] H.H. Dam, D.N. Reinhoudt, W. Verboom, Chemical Society Reviews, 36 (2007) 367-377.

[11] S.R. Daly, J.M. Keith, E.R. Batista, K.S. Boland, D.L. Clark, S.A. Kozimor, R.L. Martin, Journal of the American Chemical Society, 134 (2012) 14408-14422.

[12] G. Modolo, P. Kluxen, A. Geist, Radiochimica Acta International journal for chemical aspects of nuclear science and technology, 98 (2010) 193-201.

[13] Z. Kolarik, Chem. Rev, 108 (2008) 4208-4252.

[14] Q. Xu, J. Wu, Y. Chang, L. Zhang, Y. Yang, Radiochimica Acta International journal for chemical aspects of nuclear science and technology, 96 (2008) 771-779.

[15] T.S. Lobana, J.-C. Wang, C. Liu, Coordination chemistry reviews, 251 (2007) 91-110.

[16] C. Esterhuysen, G.J. Kruger, G. Blewett, H.G. Raubenheimer, Inorganica chimica acta, 359 (2006) 609-616.

[17] M. Ohff, A. Ohff, M.E. van der Boom, D. Milstein, Journal of the American Chemical Society, 119 (1997) 11687-11688.

[18] D.A. Albisson, R.B. Bedford, P.N. Scully, Tetrahedron letters, 39 (1998) 9793-9796.

[19] F. Miyazaki, K. Yamaguchi, M. Shibasaki, Tetrahedron letters, 40 (1999) 7379-7383.

[20] M.-H. Huang, L.-C. Liang, Organometallics, 23 (2004) 2813-2816.

[21] V.P. Böhm, W.A. Herrmann, Chemistry-A European Journal, 7 (2001) 4191-4197.

[22] J.M. V. Declerck, F. Lamaty, Synlett, 18 (2006) 3029.

[23] M. Bagherzadeh, M. Amini, A. Ellern, L.K. Woo, Inorganica Chimica Acta, 383 (2012) 46-51.

[24] V. Calò, A. Nacci, A. Monopoli, E. Ieva, N. Cioffi, Organic letters, 7 (2005) 617-620.

[25] S. Iyer, V.V. Thakur, Journal of Molecular Catalysis A: Chemical, 157 (2000) 275-278.

[26] Y. Yang, R. Zhou, S. Zhao, Q. Li, X. Zheng, Journal of Molecular Catalysis A: Chemical, 192 (2003) 303-306.

[27] I.H. C. Silvestru, J. Organomet. Chem, 365 (1989) 83-90.

[28] I. Haiduc, I. Silaghi-Dumitrescu, R. Grecu, R. Constantinescu, L. Silaghi-Dumitrescu, Journal of Molecular Structure, 114 (1984) 467-470.

[29] J. Casas, M.S. García-Tasende, A. Sánchez, J. Sordo, E. Vazquez-Lopez, E. Castellano, J.

Zukerman-Schpector, Inorganica chimica acta, 219 (1994) 115-119.

[30] J. Casas, M. García-Tasende, A. Sánchez, J. Sordo, E. Vázquez-López, Inorganica chimica acta, 256 (1997) 211-216.

[31] J. Casas, M.S. García-Tasende, A. Sánchez, J. Sordo, E. Vázquez-López, E. Castellano, J.

Zukerman-Schpector, Inorganica chimica acta, 209 (1993) 137-142.

[32] W.E. van Zyl, J.M. López-de-Luzuriaga, A.A. Mohamed, R.J. Staples, J.P. Fackler, Inorganic chemistry, 41 (2002) 4579-4589.

[33] D.L. Reger, J.E. Collins, Inorganic Chemistry, 34 (1995) 2473-2475.

[34] J.P. Fackler Jr, L. Thompson, I.J. Lin, T.A. Stephenson, R.O. Gould, J.M. Alison, A.J. Fraser, Inorganic Chemistry, 21 (1982) 2397-2403. 
[35] J.R. Phillips, J.C. Poat, A.M. Slawin, D.J. Williams, P.T. Wood, J.D. Woollins, Journal of the Chemical Society, Dalton Transactions, (1995) 2369-2375.

[36] J. Forniés, R. Navarro, V. Sicilia, M. Tomás, Inorganica chimica acta, 168 (1990) 201-207.

[37] M. Doux, C. Bouet, N. Mézailles, L. Ricard, P. Le Floch, Organometallics, 21 (2002) 2785-2788.

[38] D. Corbridge, Phosphorus: an outline of its chemistry, biochemistry, and uses, Elsevier Science Ltd, 1995.

[39] S.-B. Zhao, G.-h. Liu, D. Song, S. Wang, Dalton Transactions, (2008) 6953-6965.

[40] A. Albinati, F. Lianza, P.S. Pregosin, B. Mueller, Inorganic Chemistry, 33 (1994) 2522-2526.

[41] A. Albinati, P.S. Pregosin, F. Wombacher, Inorganic Chemistry, 29 (1990) 1812-1817.

[42] A. Albinati, C. Arz, P.S. Pregosin, Inorganic Chemistry, 26 (1987) 508-513.

[43] A. Albinati, C. Anklin, F. Ganazzoli, H. Ruegg, P.S. Pregosin, Inorganic Chemistry, 26 (1987) 503508.

[44] A.J. Canty, G. van Koten, Accounts of chemical research, 28 (1995) 406-413.

[45] J.L. Spencer, G.S. Mhinzi, J. Chem. Soc., Dalton Trans., (1995) 3819-3824.

[46] R.H. Crabtree, Angewandte Chemie International Edition in English, 32 (1993) 789-805.

[47] M. Brookhart, M.L. Green, Journal of organometallic chemistry, 250 (1983) 395-408.

[48] K. Gholivand, A. Gholami, A. Ebrahimi, S. Abolghasemi, M. Esrafili, F. Fadaei, K. Schenk, Rsc Advances, 5 (2015) 17482-17492.

[49] K. Gholivand, A. Gholami, K.J. Schenk, M.D. Esrafili, K. Farshadfar, RSC Advances, 5 (2015) 98610-98617.

[50] F. Grifasi, M.R. Chierotti, C. Garino, R. Gobetto, E. Priola, E. Diana, F. Turci, Crystal Growth \& Design, (2015).

[51] I. Taylor, M. Weininger, E. Amma, Inorganic Chemistry, 13 (1974) 2835-2842.

[52] G. Rajput, V. Singh, S.K. Singh, L.B. Prasad, M.G. Drew, N. Singh, European Journal of Inorganic Chemistry, 2012 (2012) 3885-3891.

[53] F. Sabin, C. Ryu, P. Ford, A. Vogler, Inorganic Chemistry, 31 (1992) 1941-1945.

[54] D.L. Phillips, C.-M. Che, K.H. Leung, Z. Mao, M.-C. Tse, Coordination chemistry reviews, 249

(2005) 1476-1490.

[55] K. Gholivand, F. Molaei, M. Rajabi, M.D. Esrafili, M. Hosseini, polyhedron, 71 (2014) 8-16.

[56] M.L. Kuznetsov, A.J. Pombeiro, Dalton Transactions, (2003) 738-747.

[57] W.A. Herrmann, M. Elison, J. Fischer, C. Köcher, G.R. Artus, Angewandte Chemie International

Edition in English, 34 (1995) 2371-2374.

[58] M.R. Eberhard, Organic letters, 6 (2004) 2125-2128.

[59] M.-H. Sie, Y.-H. Hsieh, Y.-H. Tsai, J.-R. Wu, S.-J. Chen, P.V. Kumar, J.-H. Lii, H.M. Lee,

Organometallics, 29 (2010) 6473-6481.

[60] S.K. Yen, L.L. Koh, F.E. Hahn, H.V. Huynh, T.A. Hor, Organometallics, 25 (2006) 5105-5112.

[61] A. Saadat, A. Banaee, P. McARDLE, K. Zare, K. Gholivand, A.A.E. Valmoozi, Journal of Chemical Sciences, 126 (2014) 1125-1133.

[62] Bruker (2005). APEX2.Bruker AXS Inc., Madison, Wisconsin, USA.

[63] Sheldrick, G. M. (1995). SADABS. University of Gottingen, Germany.

[64] L. Palatinus, G. Chapuis, Journal of Applied Crystallography, 40 (2007) 786-790.

[65] G.M. Sheldrick, Acta Crystallogr., Sect. A: Found. Crystallogr. , 64 (2008) 112.

[66] M. Frisch, G. Trucks, H. Schlegel, G. Scuseria, M. Robb, J. Cheeseman, J. Montgomery Jr, T.

Vreven, K. Kudin, J. Burant, in, Gaussian.

[67] P.J. Hay, W.R. Wadt, The Journal of Chemical Physics, 82 (1985) 299-310.

[68] A.E. Reed, L.A. Curtiss, F. Weinhold, Chemical Reviews, 88 (1988) 899-926.

[69] S.F. Boys, F.d. Bernardi, Molecular Physics, 19 (1970) 553-566. 


\section{Figure Captions}

Fig. 1: ORTEP view of C1 (left) and C2 (right) (50\% probability level) with atom-labeling scheme (part of atom-labeling are omitted for clarity).

Fig. 2: Side view representation of C1, showing intermolecular S1...H1-N1 (2.56 $\AA$ ), Pd...H-C $(3.324 \AA)$ and C-H... $\pi$ interactions $\left(\mathrm{C} 8 \mathrm{~A}-\mathrm{H} 8 \mathrm{~A} \ldots \mathrm{Cg}: \mathrm{d}_{\mathrm{H} . . . \mathrm{C}}=2.983 \AA, \mathrm{d}_{\mathrm{C} \ldots \mathrm{Cg}}=3.921 \AA, \theta=\right.$ $\left.137.867^{\circ}\right)$.

Fig. 3: 2D nonclassical hydrogen-bonded frameworks of C1, showing O1...H11-C11 (2.550 $\AA$ ) and S2...H5-C5 (2.791 А).

Fig. 4: 2D nonclassical hydrogen-bonded frameworks of C2, showing S1 ...H25A-C25A (2.925 $\AA$ ) and $\mathrm{S} 1 \ldots \mathrm{H} 6 \mathrm{~A}-\mathrm{C} 6 \mathrm{~A}(3.011 \AA)$.

Fig. 5: Optimized structures at B3LYP/6-311+G*/LANL2DZ level (Hydrogen atoms are omitted for clarity).

Fig. 6: The time-yield curves for the coupling of $\mathrm{PhBr}$ with styrene at $100{ }^{\circ} \mathrm{C}$ in optimized reaction conditions, catalyzed by $\mathrm{C} 1$ and $\mathrm{C} 2$ catalysts.

Scheme 1: Synthesis of C1 and C2 complexes. 
Table 1: Selected geometrical parameters for $\mathrm{C} 1$ and $\mathrm{C} 2$ in solid state and in gas phase calculated at B3LYP/6-311+G* (L and C2) and at B3LYP/LANL2DZ/6-311+G* (C1).

\begin{tabular}{|c|c|c|c|c|c|}
\hline \multirow[t]{2}{*}{ copmounds } & \multicolumn{2}{|l|}{$\mathrm{C} 1$} & \multicolumn{2}{|l|}{$\mathrm{C} 2$} & \multirow{2}{*}{$\begin{array}{l}\text { L } \\
\text { Calc. }\end{array}$} \\
\hline & X-ray & Calc. & X-ray & Calc. & \\
\hline \multicolumn{6}{|c|}{ Bond lengths $(\AA)$} \\
\hline \multirow[t]{2}{*}{ P-S } & $2.0156(6)$ & 2.048 & $1.9913(6)$ & 2.041 & 2.019 \\
\hline & $2.0336(6)$ & 2.053 & $2.0330(6)$ & 2.060 & 2.025 \\
\hline P-N & $1.6282(15)$ & 1.681 & $1.6738(16)$ & 1.689 & 1.688 \\
\hline \multirow[t]{2}{*}{$M-S_{t}^{a}$} & $2.3427(4)$ & 2.423 & $2.3857(6)$ & 2.338 & \\
\hline & $2.3431(4)$ & 2.424 & & 2.429 & \\
\hline $\mathrm{M}-\mathrm{S}_{\mathrm{b}}^{\mathrm{b}}$ & & & $\begin{array}{l}2.3084(7) \\
2.6147(6)\end{array}$ & & \\
\hline M-P & & & $2.2219(6)$ & 2.222 & \\
\hline M...M & & & $2.8396(6)$ & 3.736 & \\
\hline \multicolumn{6}{|c|}{ Bond angles $\left({ }^{\circ}\right)$} \\
\hline S-P-S & $101.36(2)$ & 103.05 & $112.79(3)$ & 113.26 & 100.63 \\
\hline \multirow[t]{2}{*}{$\mathrm{S}_{\mathrm{t}}-\mathrm{M}-\mathrm{S}_{\mathrm{t}}$} & $83.905(14)$ & 82.97 & 105.153(19) & 105.14 & \\
\hline & $96.095(15)$ & 97.02 & & & \\
\hline $\mathrm{S}_{\mathrm{b}}-\mathrm{M}-\mathrm{S}_{\mathrm{b}}$ & & & $84.052(17)$ & & \\
\hline
\end{tabular}

${ }^{\mathrm{a}} \mathrm{S}$ : terminal $\mathrm{S}$ atom. ${ }^{\mathrm{b}} \mathrm{S}$ : bridge $\mathrm{S}$ atom 
Table 2: Atomic Charge Distributions (e) and Natural Electron Configurations calculated for selected atoms in $\mathrm{L}, \mathrm{C} 1$ and $\mathrm{C} 2$.

\begin{tabular}{|c|c|c|c|}
\hline atoms & $\mathrm{L}$ & $\mathrm{C} 1$ & $\mathrm{C} 2$ \\
\hline $\begin{array}{l}\mathrm{M}= \\
\mathrm{Pd}, \mathrm{Cu}\end{array}$ & & $\begin{array}{l}-0.07 \\
{[\text { core }] 5 \mathrm{~s}^{0.37} 4 \mathrm{~d}^{9.19} 5 \mathrm{p}^{0.49} 6 \mathrm{~s}^{0.01} 5 \mathrm{~d}^{0.01}}\end{array}$ & $\begin{array}{l}+0.829 \\
{[\text { core }] 4 \mathrm{~s}^{0.40} 3 \mathrm{~d}^{9.74} 4 \mathrm{p}^{0.02} 5 \mathrm{~s}^{0.01}}\end{array}$ \\
\hline S & $\begin{array}{l}-0.71 \\
{[\text { core }] 3 \mathrm{~s}^{1.84} 3 \mathrm{p}^{4.84} 3 \mathrm{~d}^{0.01} 5 \mathrm{p}^{0.01}} \\
-0.72 \\
{\left[\text { core] } 3 \mathrm{~s}^{1.84} 3 \mathrm{p}^{4.86} 3 \mathrm{~d}^{0.01} 5 \mathrm{p}^{0.01}\right.}\end{array}$ & $\begin{array}{l}-0.39 \\
{[\text { core }] 3 \mathrm{~s}^{1.79} 3 \mathrm{p}^{4.58} 3 \mathrm{~d}^{0.01}} \\
-0.37 \\
{[\text { core }] 3 \mathrm{~s}^{1.78} 3 \mathrm{p}^{4.56} 3 \mathrm{~d}^{0.01}}\end{array}$ & $\begin{array}{l}-0.69^{\mathrm{a}} \\
{[\text { core }] 3 \mathrm{~s}^{1.81} 3 \mathrm{p}^{4.85} 3 \mathrm{~d}^{0.01} 4 \mathrm{p}^{0.01}} \\
-0.77^{\mathrm{b}} \\
{[\text { core }] 3 \mathrm{~s}^{1.81} 3 \mathrm{p}^{4.93} 3 \mathrm{~d}^{0.02} 4 \mathrm{p}^{0.02}}\end{array}$ \\
\hline $\mathrm{P}$ & {$[$ core $] 3 \mathrm{~s}^{1.13} 3 \mathrm{p}^{2.50} 3 \mathrm{~d}^{0.08} 5 \mathrm{p}^{0.03}$} & $\begin{array}{l}+1.36 \\
{[\text { core }] 3 \mathrm{~s}^{1.11} 3 \mathrm{p}^{2.42} 3 \mathrm{~d}^{0.08} 4 \mathrm{p}^{0.02}}\end{array}$ & $\begin{array}{l}+1.36 \\
{[\text { core }] 3 \mathrm{~s}^{1.04} 3 \mathrm{p}^{2.44} 3 \mathrm{~d}^{0.09} 4 \mathrm{p}^{0.06}} \\
+0.75^{\mathrm{c}} \\
{[\text { core }] 3 \mathrm{~s}^{1.26} 3 \mathrm{p}^{2.87} 4 \mathrm{~s}^{0.01} 3 \mathrm{~d}^{0.03} 4 \mathrm{p}^{0.0}}\end{array}$ \\
\hline $\mathrm{N}$ & $\begin{array}{l}-1.00 \\
{[\text { core }] 2 \mathrm{~s}^{1.44} 2 \mathrm{p}^{4.53} 3 \mathrm{p}^{0.01} 4 \mathrm{p}^{0.01}}\end{array}$ & $\begin{array}{l}-0.98 \\
{[\text { core }] 2 \mathrm{~s}^{1.40} 2 \mathrm{p}^{4.56} 3 \mathrm{p}^{0.01} 4 \mathrm{p}^{0.01}}\end{array}$ & $\begin{array}{l}-0.97 \\
{[\text { core }] 2 \mathrm{~s}^{1.38} 2 \mathrm{p}^{4.57} 3 \mathrm{p} 0.01}\end{array}$ \\
\hline
\end{tabular}

${ }^{\text {a}}$ Related to terminal $\mathrm{S}$ atom. ${ }^{\mathrm{b}}$ Related to bridge $\mathrm{S}$ atom. ${ }^{\mathrm{c}}$ Related to $\mathrm{PPh}_{3}$ moiety. 
Table 3: Solvent and base effects on the Heck coupling of $\mathrm{PhBr}$ with styrene. ${ }^{\mathrm{a}}$

\begin{tabular}{|c|c|c|c|c|}
\hline \multirow[b]{2}{*}{ Entry } & \multirow[b]{2}{*}{ solvent } & \multirow[b]{2}{*}{ base } & \multicolumn{2}{|c|}{ Yield $(\%)^{c}$ (isolayed yield $\left.(\%)\right)^{d}$} \\
\hline & & & $\mathrm{C} 1$ & $\mathrm{C} 2$ \\
\hline 1 & DMF & $\mathrm{K}_{2} \mathrm{CO}_{3}$ & $68(61)$ & 24 \\
\hline 2 & NMP & $\mathrm{K}_{2} \mathrm{CO}_{3}$ & 63 & 24 \\
\hline 3 & isopropanol & $\mathrm{K}_{2} \mathrm{CO}_{3}$ & 8 & 8 \\
\hline 4 & toluene & $\mathrm{K}_{2} \mathrm{CO}_{3}$ & 33 & 13 \\
\hline 5 & dioxane & $\mathrm{K}_{2} \mathrm{CO}_{3}$ & 39 & 11 \\
\hline 6 & DMF & $\mathrm{K}_{3} \mathrm{PO}_{4}$ & 61 & $44(38)$ \\
\hline 7 & DMF & $\mathrm{NaOH}$ & 21 & 16 \\
\hline 8 & DMF & $\mathrm{Et}_{3} \mathrm{~N}$ & 13 & trace \\
\hline 9 & DMF & pyridine & 6 & trace \\
\hline 10 & NMP & $\mathrm{K}_{3} \mathrm{PO}_{4}$ & 55 & 41 \\
\hline
\end{tabular}

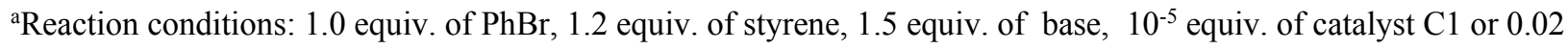
equiv. of catalyst $\mathrm{C} 2,2 \mathrm{~mL}$ of solvent. ${ }^{b} \mathrm{Bath}$ temperature. ${ }^{\mathrm{c}}$ Determined by $\mathrm{GC}$, based on $\mathrm{PhBr}$ (dodecane as an internal standard); average of two runs. ${ }^{\mathrm{d}}$ Isolated yield ; average of two runs. 
Table 4: Effect of catalyst loading a

\begin{tabular}{|c|c|c|c|c|}
\hline Entry & $\mathrm{X}$ & Catalyst (equiv) & Yield $(\%)^{b}$ & TON \\
\hline 1 & $\mathrm{Br}$ & C1 (0.000010) & 68 & 68000 \\
\hline 2 & $\mathrm{Br}$ & C1 $(0.000015)$ & 86 & 57330 \\
\hline 3 & $\mathrm{Br}$ & C1 (0.000018) & 91 & 50550 \\
\hline 4 & $\mathrm{Br}$ & C1 (0.000020) & 94 & 47000 \\
\hline 5 & $\mathrm{Br}$ & C1 (0.000022) & 93 & 42270 \\
\hline 6 & $\mathrm{Br}$ & $\mathrm{C} 1(0.000030)$ & 96 & 32000 \\
\hline 7 & I & $\mathrm{C} 1(0.000005)$ & 73 & 146000 \\
\hline 8 & I & C1 (0.000008) & 95 & 118750 \\
\hline 9 & I & C1 (0.000010) & 100 & 100000 \\
\hline 11 & $\mathrm{Br}$ & C2 (0.02) & 44 & 22 \\
\hline 12 & $\mathrm{Br}$ & C2 (0.04) & 61 & 15 \\
\hline 13 & $\mathrm{Br}$ & C2 (0.08) & 72 & 9 \\
\hline 14 & $\mathrm{Br}$ & C2 (0.10) & 83 & 8 \\
\hline 15 & $\mathrm{Br}$ & C2 (0.12) & 84 & 7 \\
\hline 16 & I & C2 (0.020) & 71 & 36 \\
\hline 17 & I & $\mathrm{C} 2(0.030)$ & 96 & 32 \\
\hline 18 & I & C2 (0.040) & 98 & 25 \\
\hline
\end{tabular}

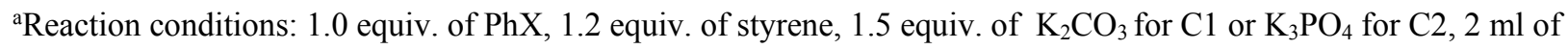
DMF. ${ }^{b}$ Determined by GC, based on $\mathrm{PhX}$ (dodecane as an internal standard); average of two runs. 
Table 5. Crystallographic data for compounds $\mathrm{C} 1$ and $\mathrm{C} 2$.

\begin{tabular}{|c|c|c|}
\hline Compound & $\mathrm{C} 1$ & $\mathrm{C} 2$ \\
\hline Empirical formula & $\mathrm{C}_{28} \mathrm{H}_{30} \mathrm{~N}_{2} \mathrm{O}_{2} \mathrm{P}_{2} \mathrm{PdS}_{4}$ & $\mathrm{C}_{32} \mathrm{H}_{60} \mathrm{Cu}_{2} \mathrm{~N}_{2} \mathrm{O}_{2} \mathrm{P}_{4} \mathrm{~S}_{4}$ \\
\hline Formula weight & 723.12 & 1268.34 \\
\hline Temperature (K) & $100(2)$ & $100(2)$ \\
\hline Wavelength $(\AA)$ & $0.71073 \AA$ & $0.71073 \AA$ \\
\hline Crystal system, space group & Monoclinic, $\mathrm{P} 2_{1} / \mathrm{c}$ & Monoclinic, $\mathrm{P} 2_{1} / \mathrm{n}$ \\
\hline$a(\AA)$ & $11.0212(5)$ & $13.631(2)$ \\
\hline$b(\AA)$ & $16.2526(7)$ & $10.5473(15)$ \\
\hline$c(\AA)$ & $8.5432(4)$ & $20.374(3)$ \\
\hline$\alpha /{ }^{\circ}$ & 90 & 90 \\
\hline$\beta /{ }^{\circ}$ & $101.168(2)$ & $95.531(2)$ \\
\hline$\gamma /{ }^{\circ}$ & 90 & 90 \\
\hline$V\left(\AA^{3}\right)$ & $1501.31(12)$ & $2915.6(7)$ \\
\hline$Z$, Calculated density $\left({\left.\mathrm{g} . \mathrm{cm}^{-3}\right)}^{-3}\right.$ & $2,1.600$ & $2,1.445$ \\
\hline Absorption coefficient $\left(\mathrm{mm}^{-1}\right)$ & 1.033 & 1.029 \\
\hline$F(000)$ & 736.0 & 1312.0 \\
\hline Crystal size $\left(\mathrm{mm}^{3}\right)$ & $0.260 \times 0.120 \times 0.100$ & $0.350 \times 0.240 \times 0.200$ \\
\hline$\theta$ range for data collection $\left(^{\circ}\right)$ & 4.524 to 66.438 & 4.016 to 61.088 \\
\hline \multirow[t]{3}{*}{ Index ranges } & $-13 \leq \mathrm{h} \leq 16$ & $-19 \leq \mathrm{h} \leq 19$ \\
\hline & $-25 \leq \mathrm{k} \leq 23$ & $-15 \leq \mathrm{k} \leq 14$ \\
\hline & $-12 \leq 1 \leq 13$ & $-28 \leq 1 \leq 29$ \\
\hline Reflections collected & 14026 & 34056 \\
\hline Independent reflections & $\begin{array}{l}5396\left[\mathrm{R}_{\text {int }}=0.0249, \mathrm{R}_{\text {sigma }}=\right. \\
0.0362]\end{array}$ & $\begin{array}{l}8871\left[R_{\text {int }}=0.0326, R_{\text {sigma }}=\right. \\
0.0306]\end{array}$ \\
\hline Data/restraints/parameters & $5396 / 12 / 187$ & $8871 / 0 / 357$ \\
\hline Goodness-of-fit on $F^{2}$ & 1.040 & 1.047 \\
\hline Final $R$ indices & $\mathrm{R}_{1}=0.0321, \mathrm{wR}_{2}=0.0635$ & $\mathrm{R}_{1}=0.0374, \mathrm{wR}_{2}=0.0969$ \\
\hline$R$ indices (all data) & $\mathrm{R}_{1}=0.0488, \mathrm{wR}_{2}=0.0691$ & $\mathrm{R}_{1}=0.0479, \mathrm{wR}_{2}=0.1018$ \\
\hline Largest diff. peak and hole $\left(\mathrm{e} . \AA^{-3}\right)$ & $0.93 /-0.44$ & $1.08 /-0.38$ \\
\hline
\end{tabular}



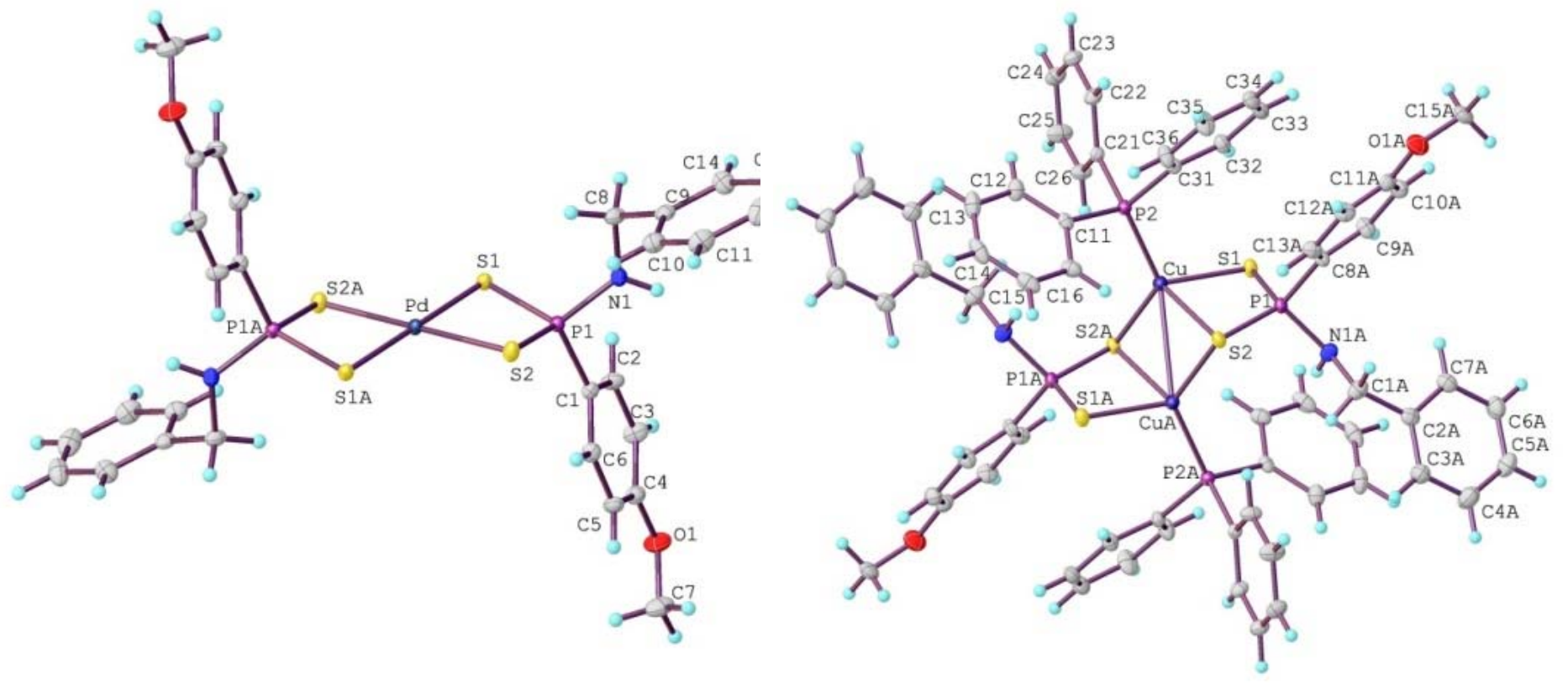

Fig. 1 


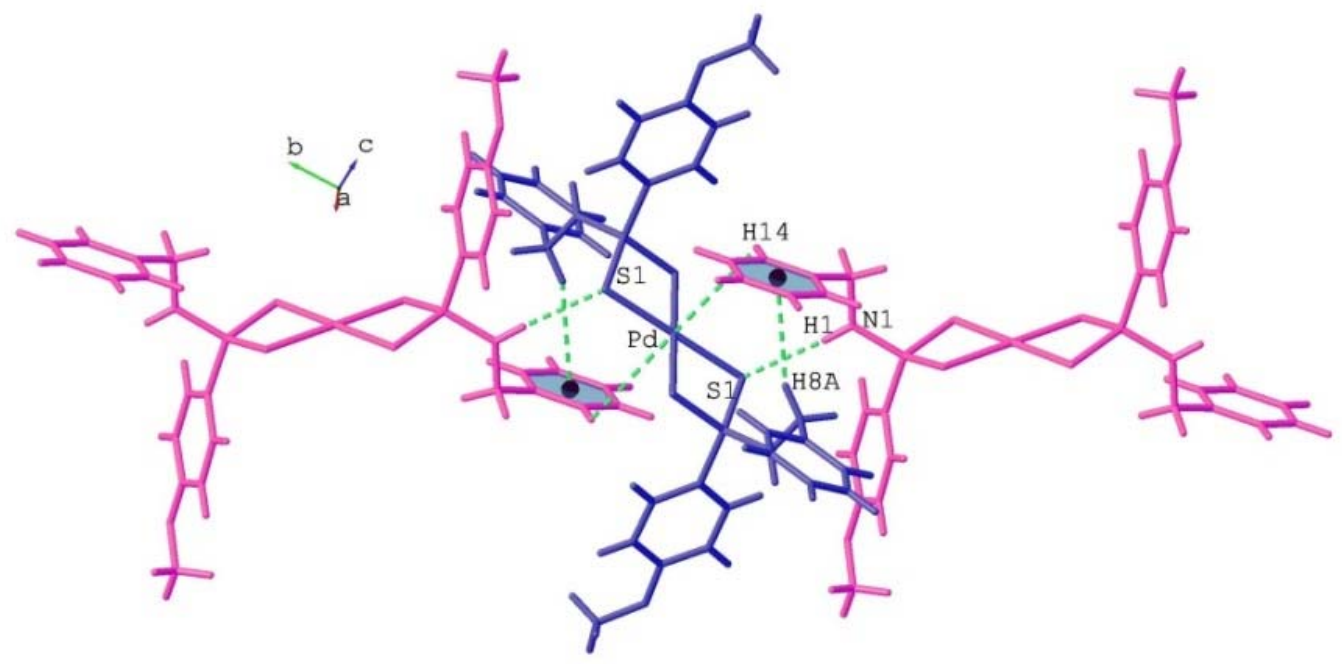

Fig. 2 


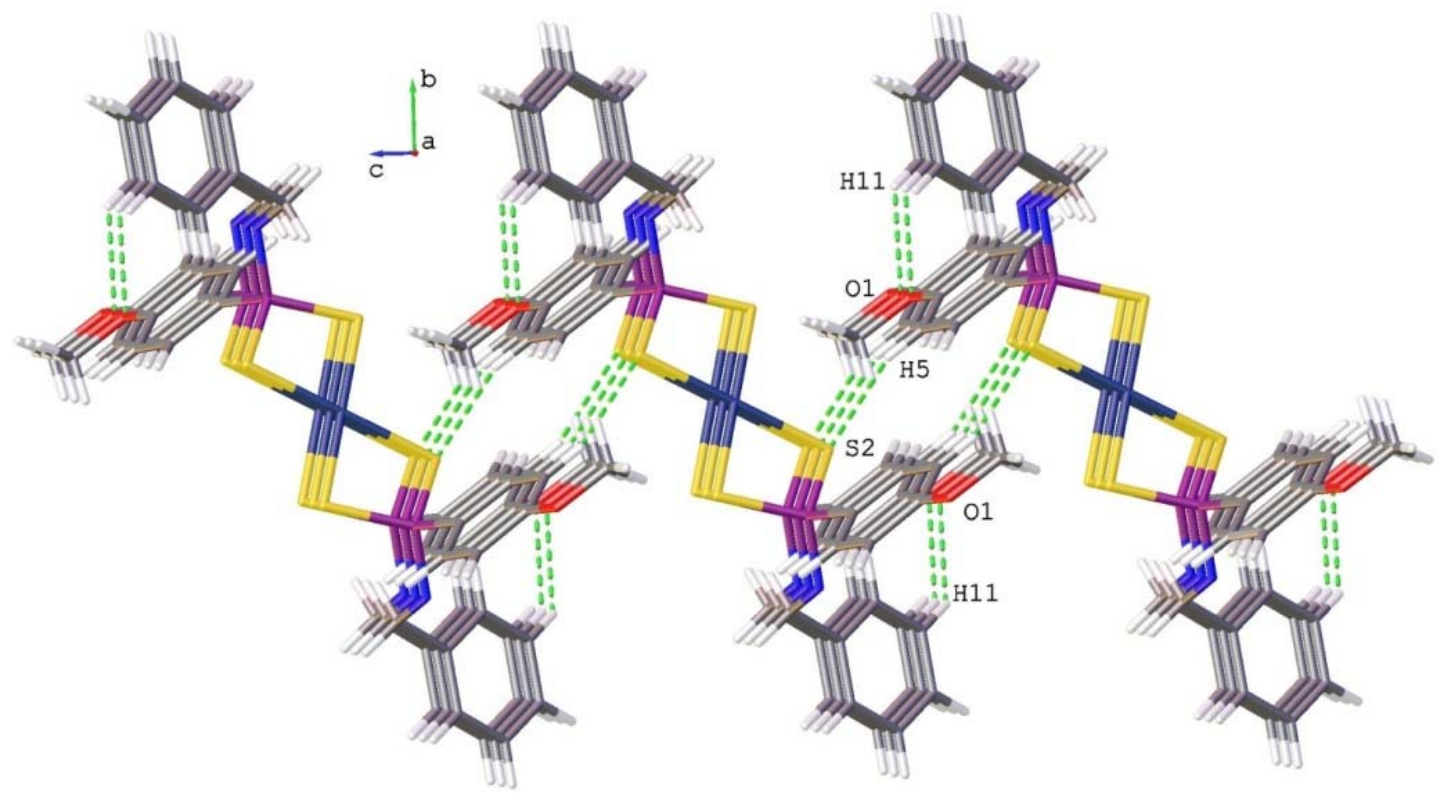

Fig. 3 


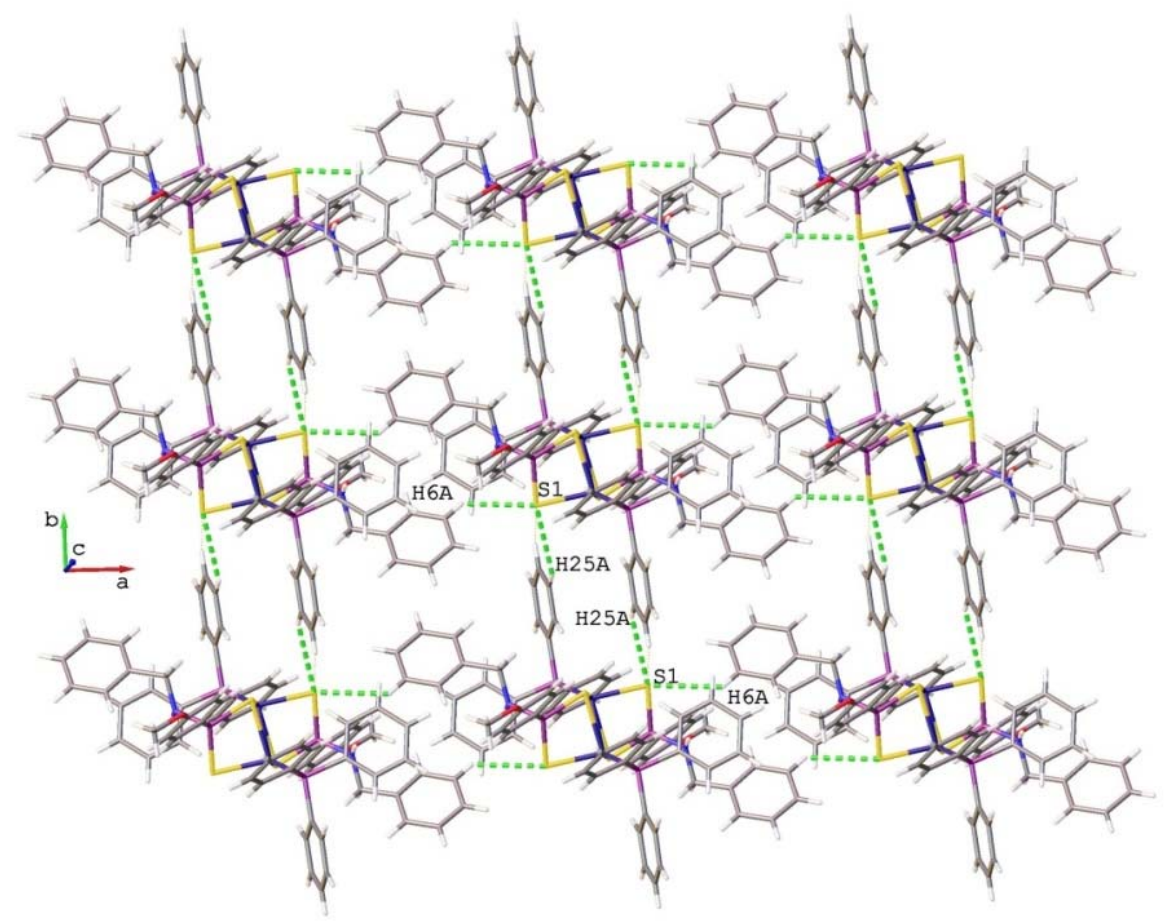

Fig. 4 


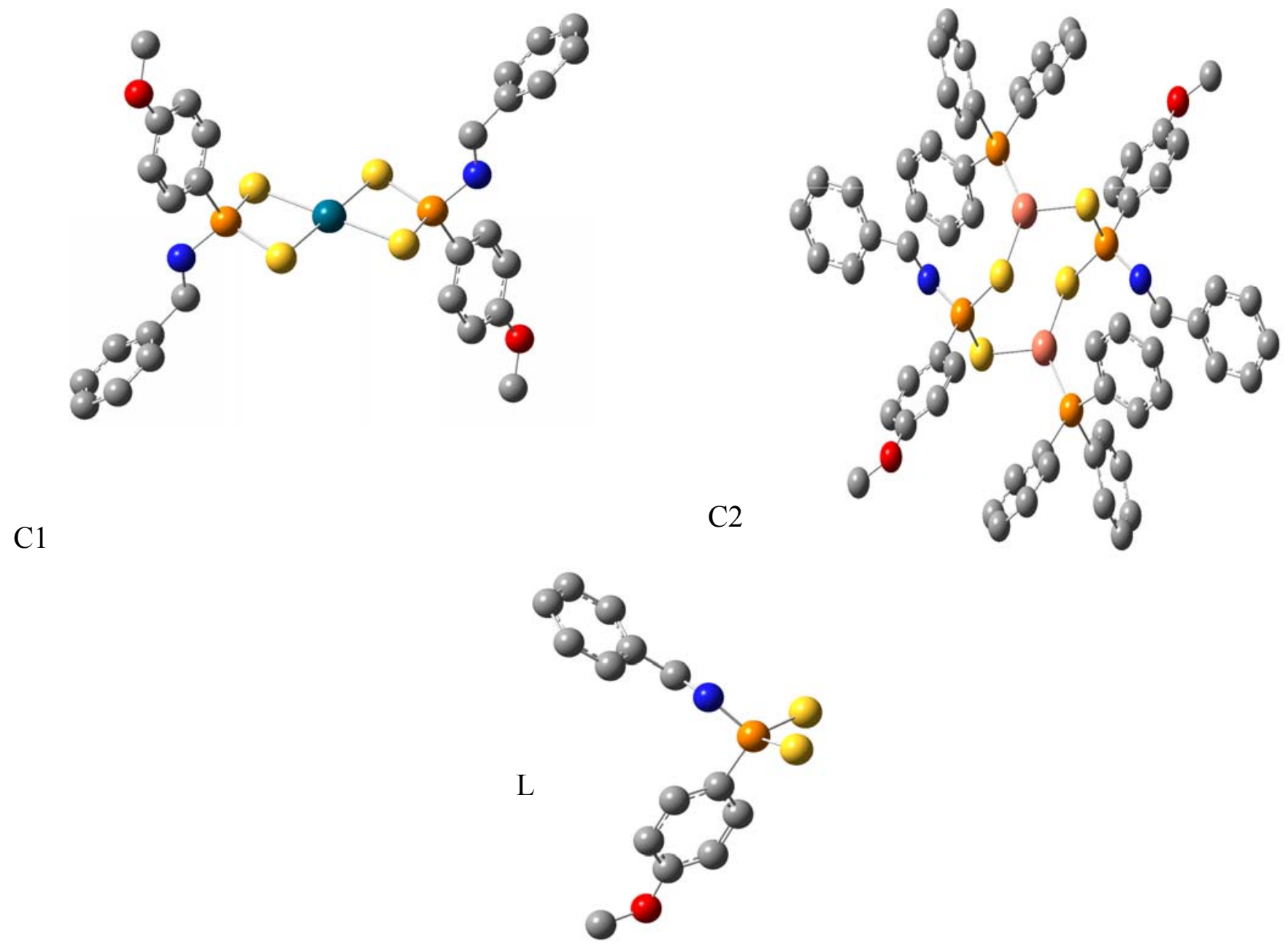

Fig. 5 


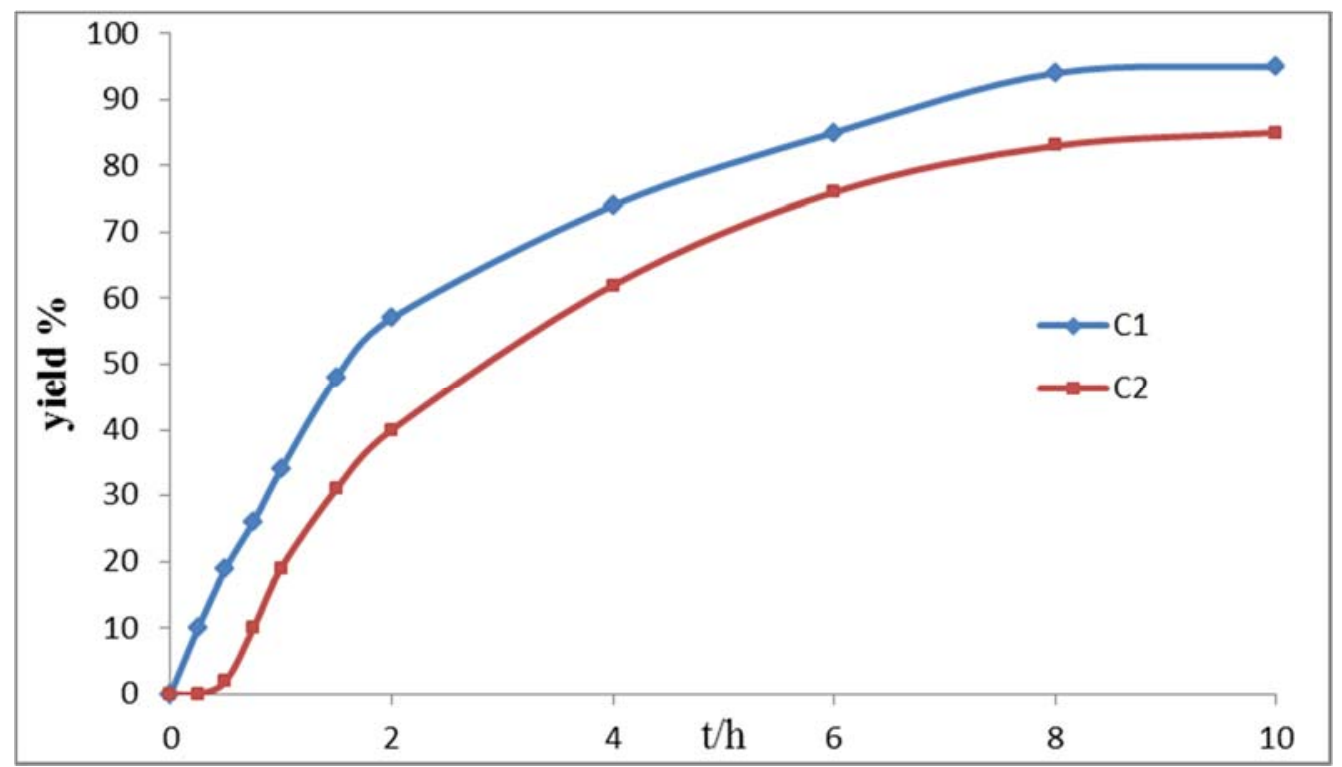

Fig. 6 


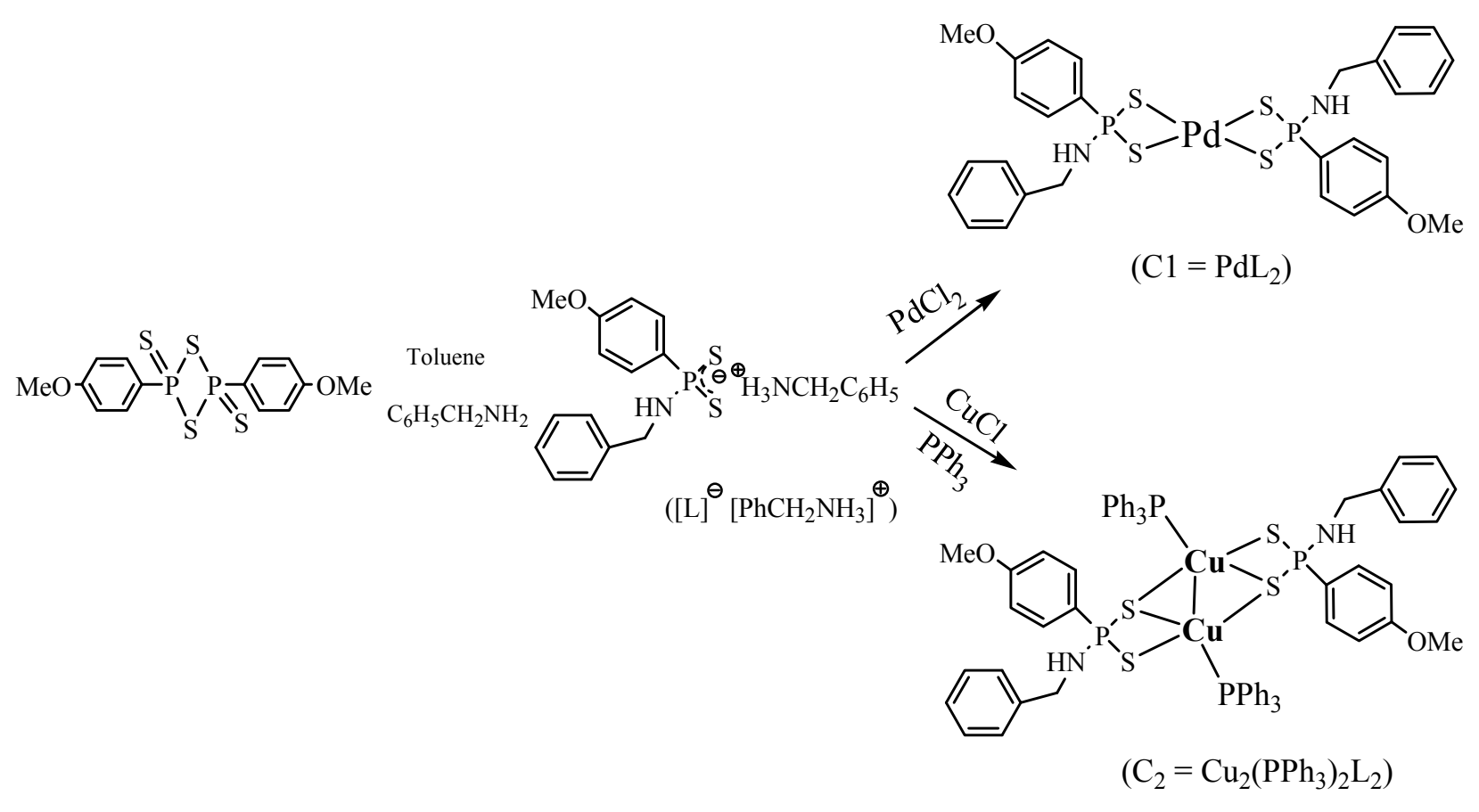

Scheme 1 
Synthesis and structural characterization of $\mathrm{Pd}(\mathrm{II})$ and $\mathrm{Cu}(\mathrm{I})$ complexes containing dithiophosphorus ligand and their catalytic activities for Heck reaction Khodayar Gholivand $^{\mathrm{a}^{*}}$, Rasoul Salami ${ }^{\mathrm{a}}$, Kaveh Farshadfar ${ }^{\mathrm{a}}$, Raymond J. Butcher ${ }^{\mathrm{b}}$

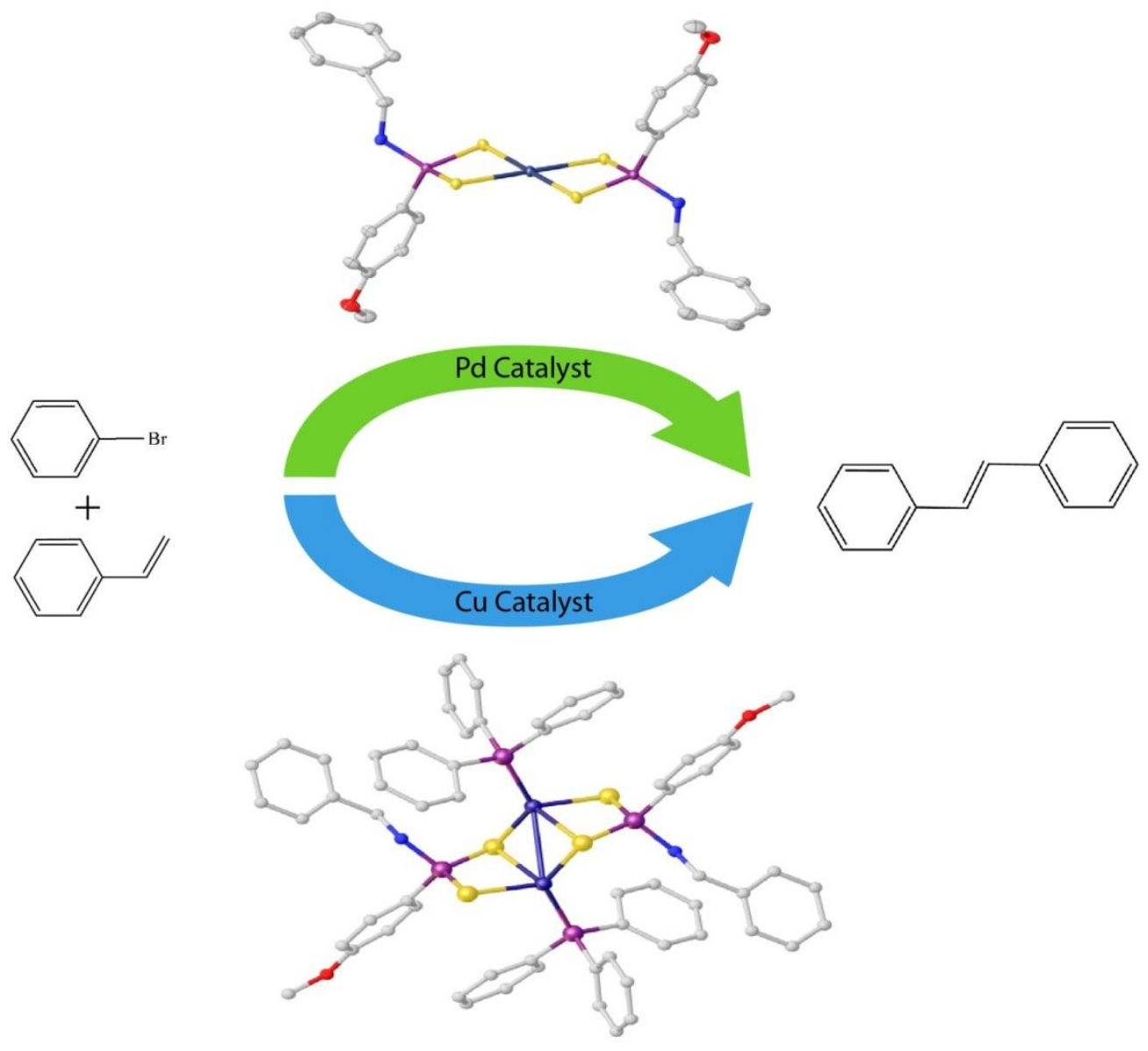

